\title{
Tandem or sequential coupling-IMDA cycloaddition approach to the highly fused polycarbocycles
}

\author{
Soo-Jin Pang, Soo-Hyun Min, Haiwon Lee and Cheon-Gyu Cho* \\ Department of Chemistry, Hanyang University, Seoul, Korea
}

\section{Supporting Information}

Table of Contents

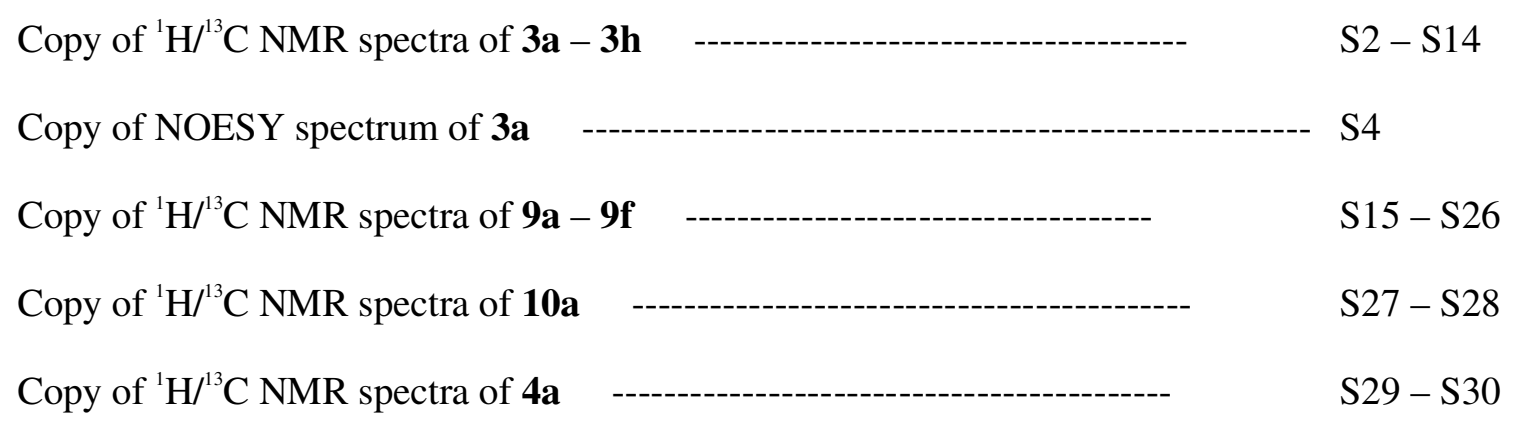




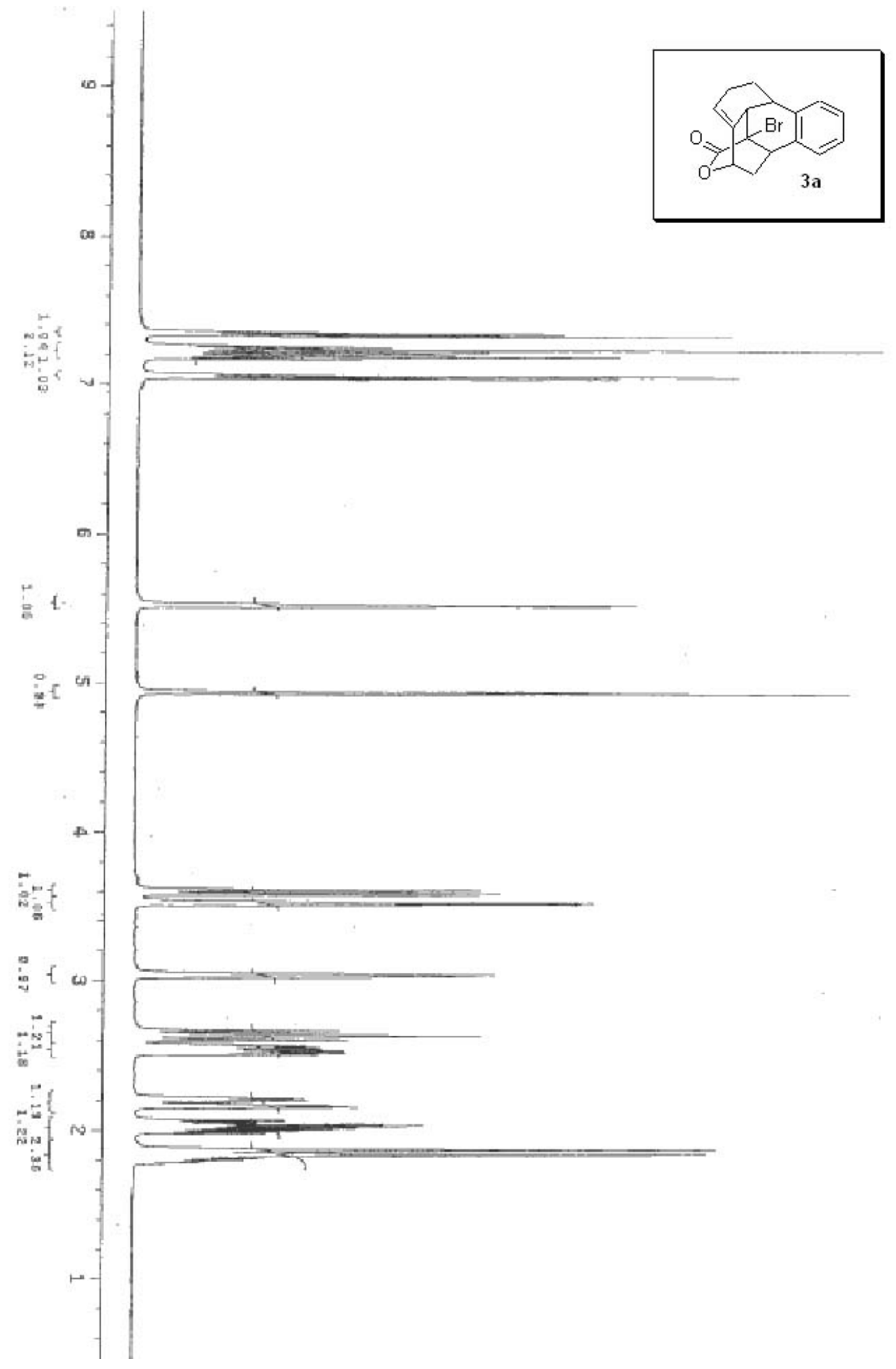




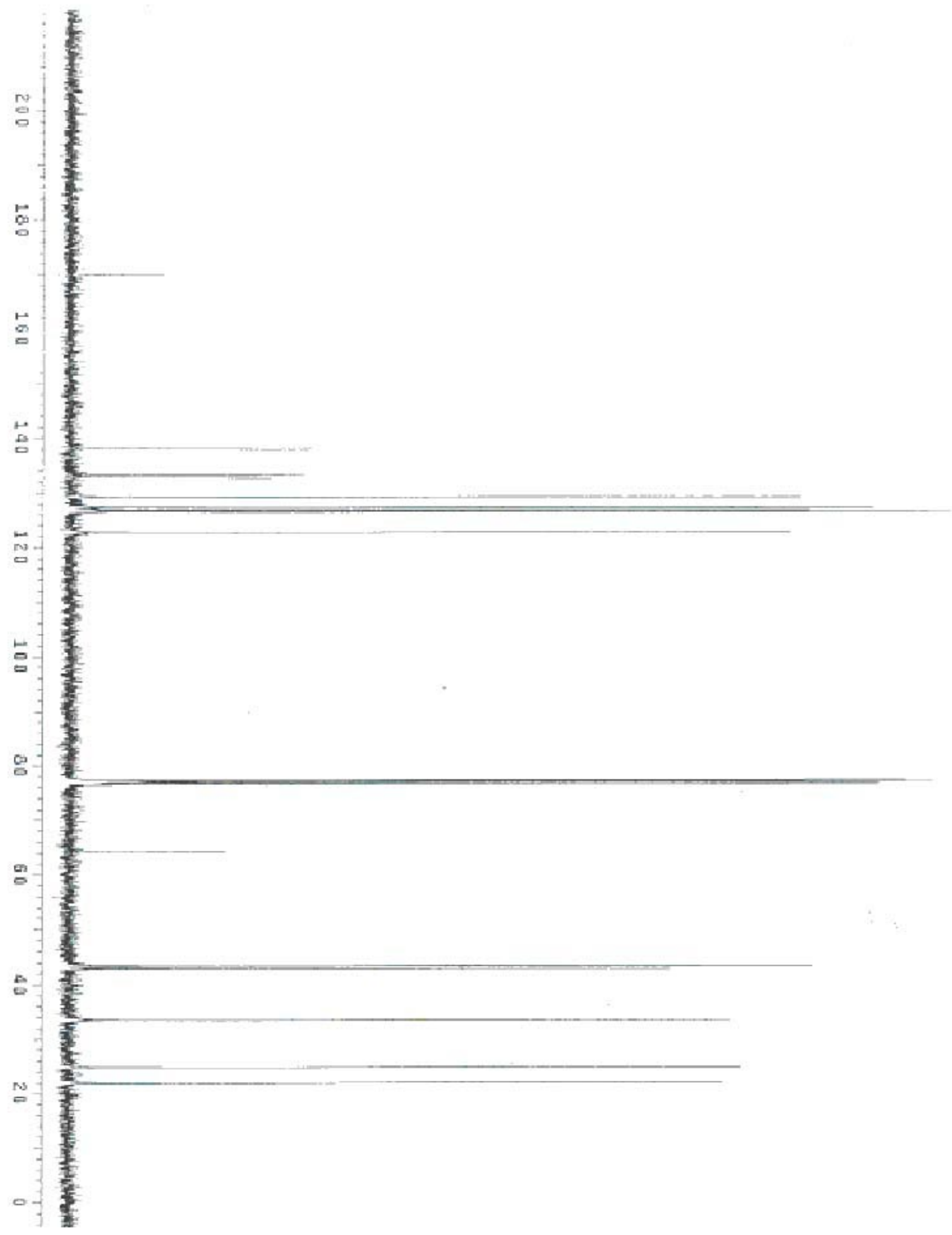




\section{NOESY SPECTRUM OF 3a}
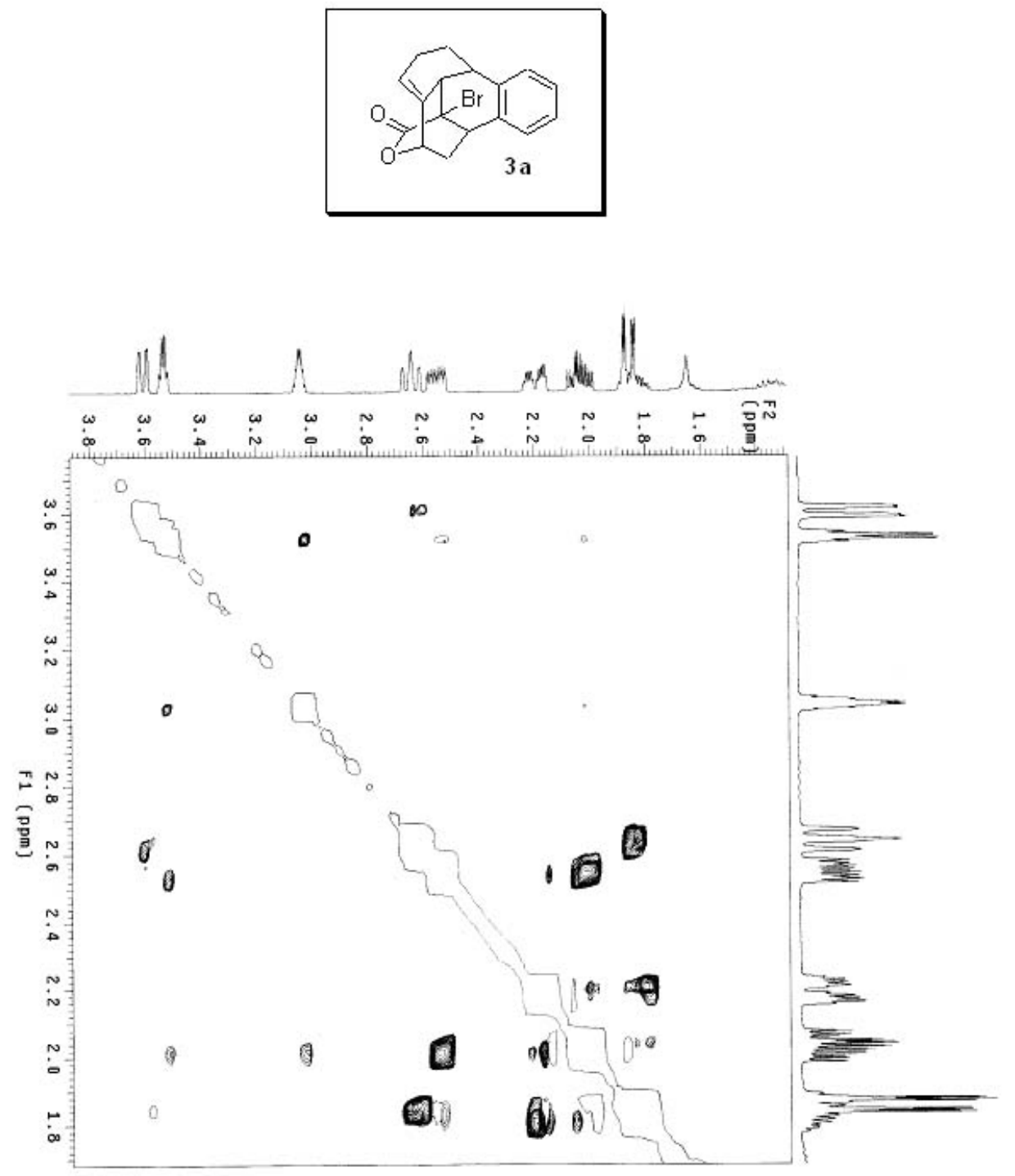


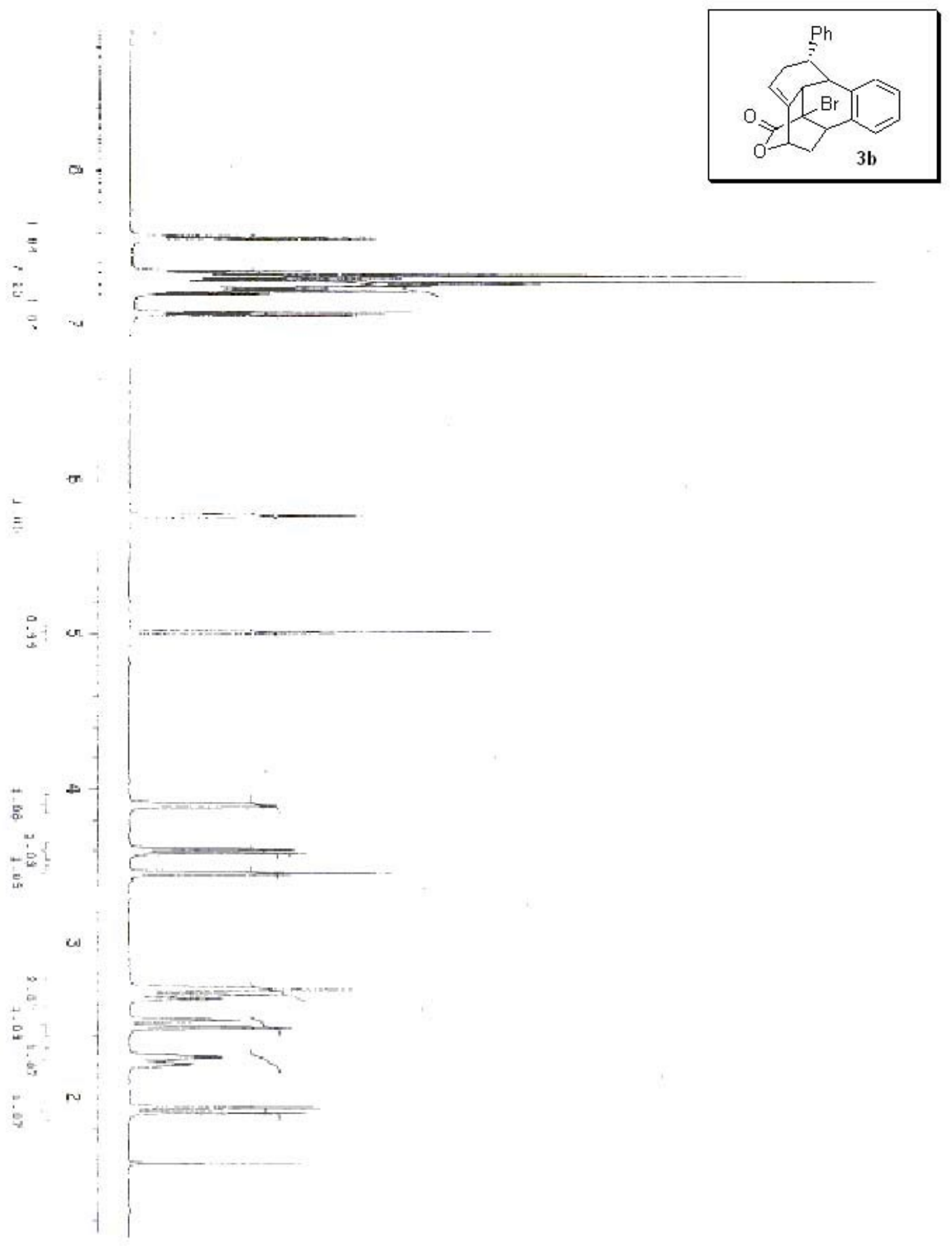




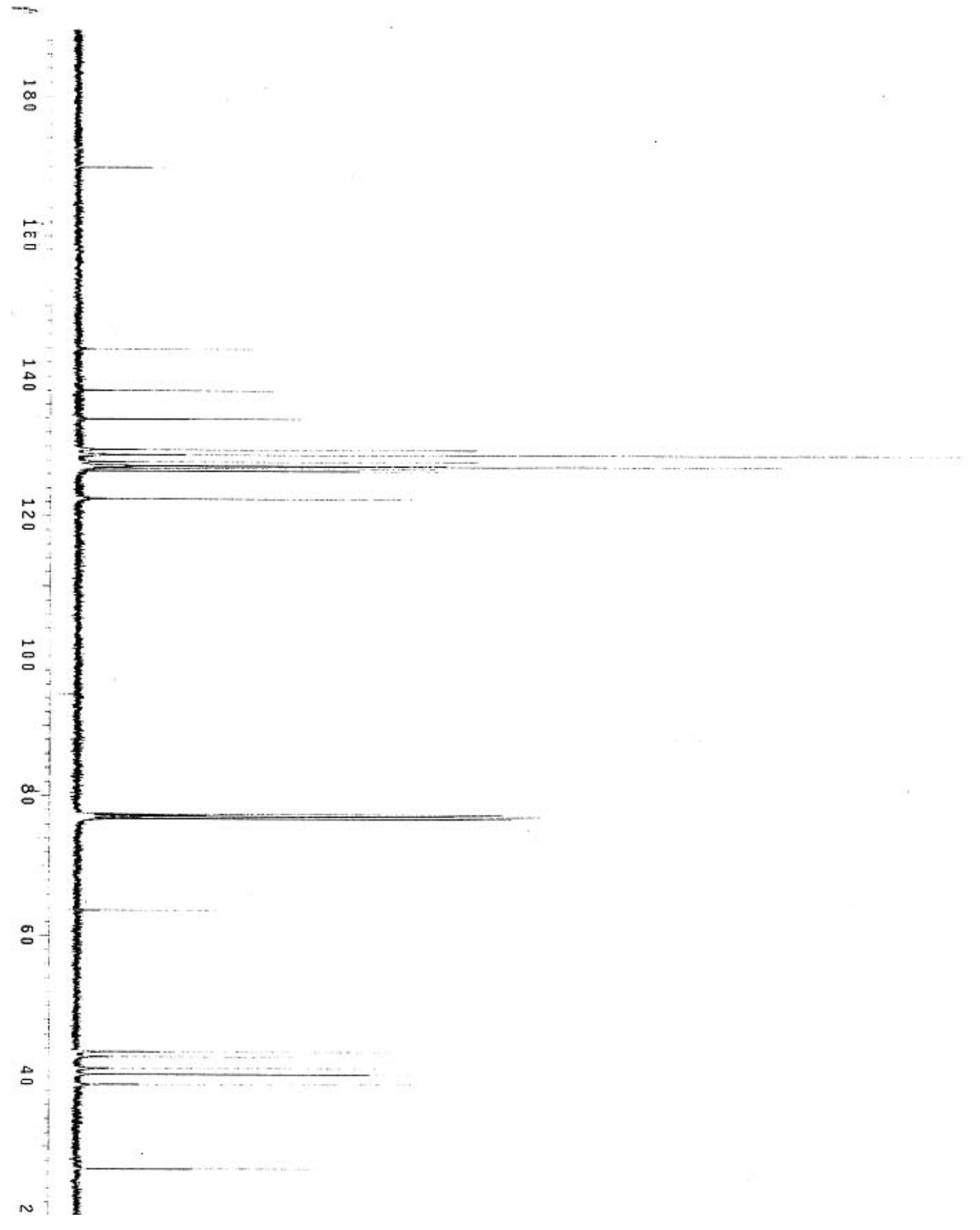

S6 


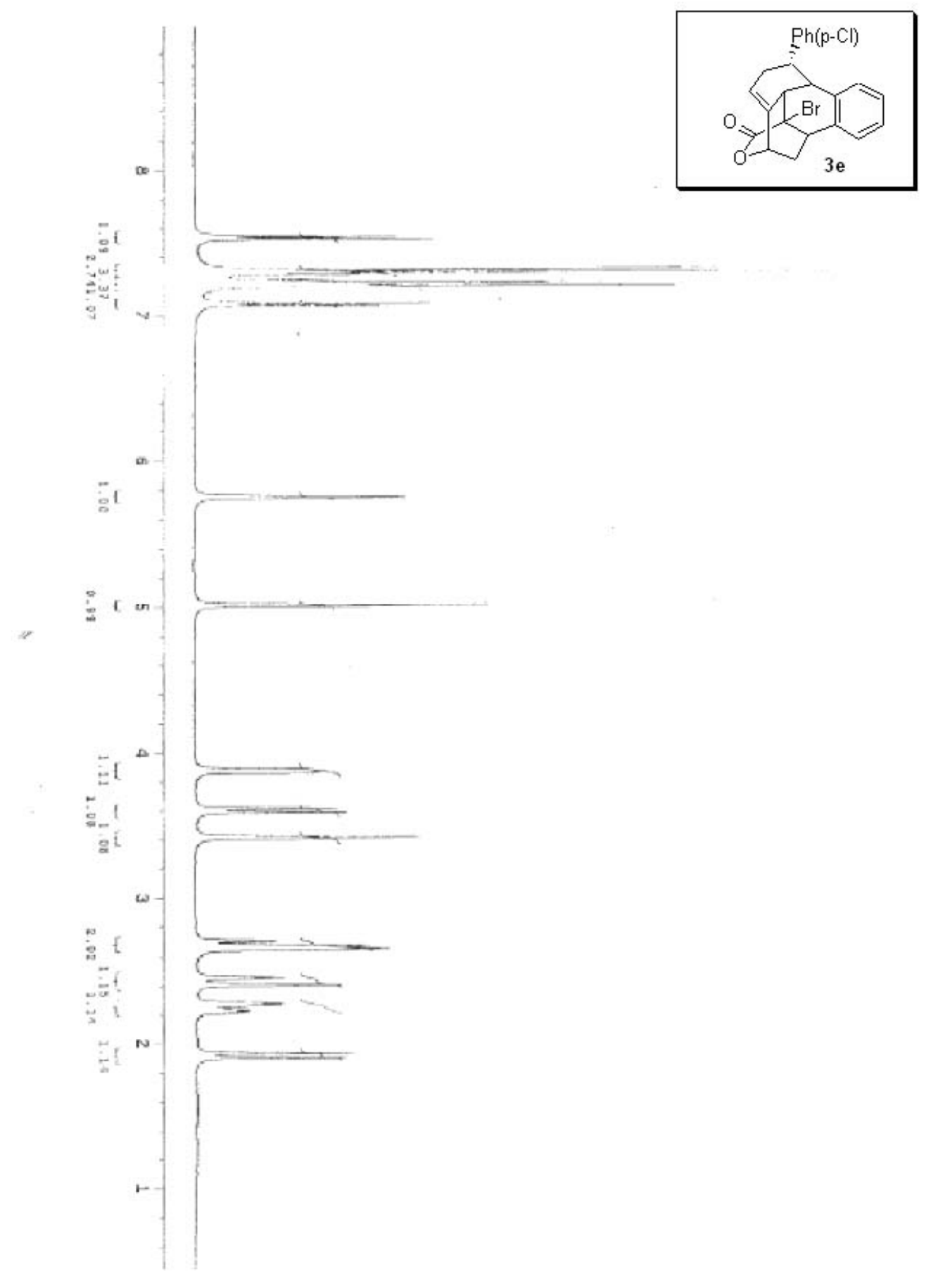




$$
F
$$




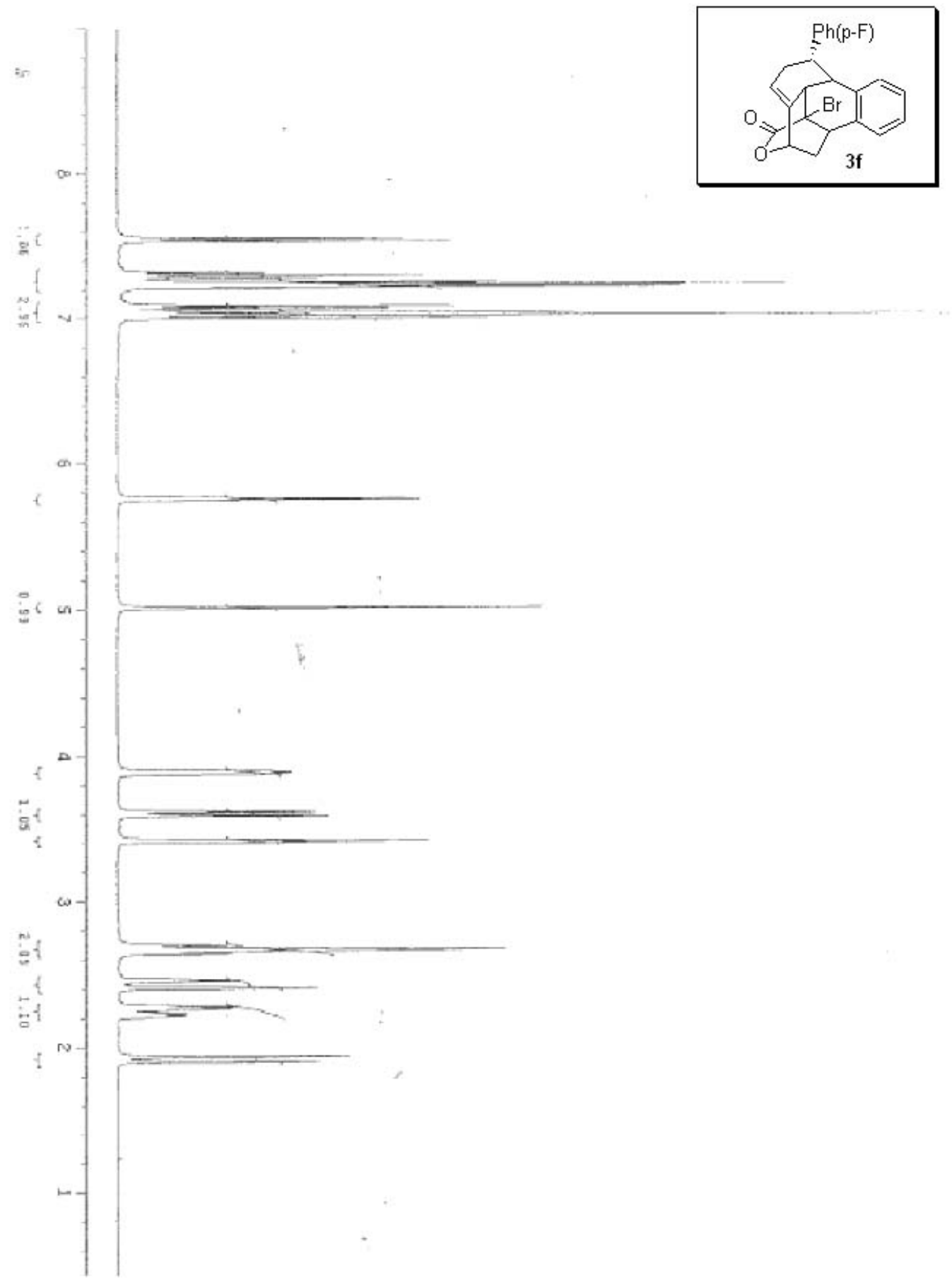




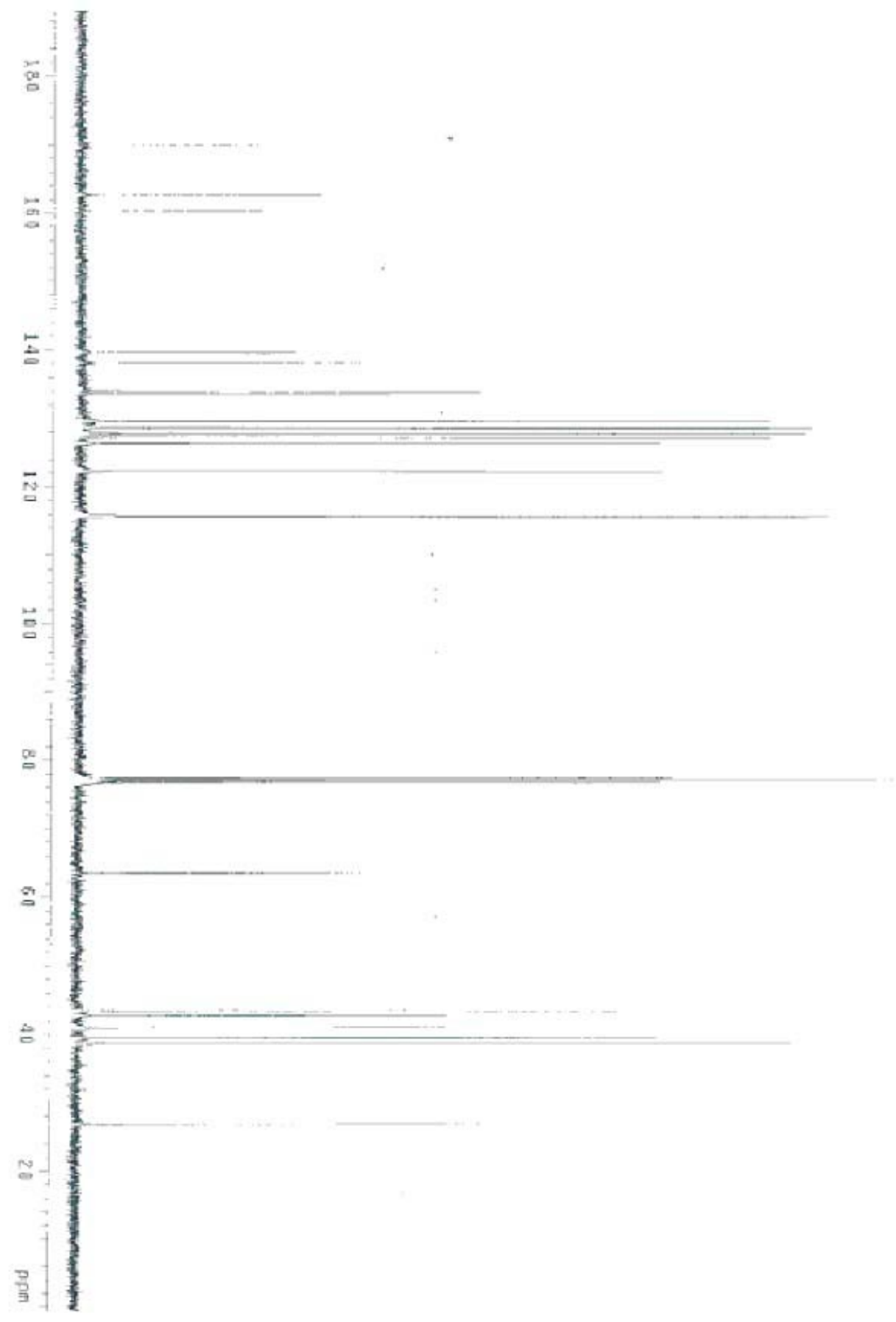




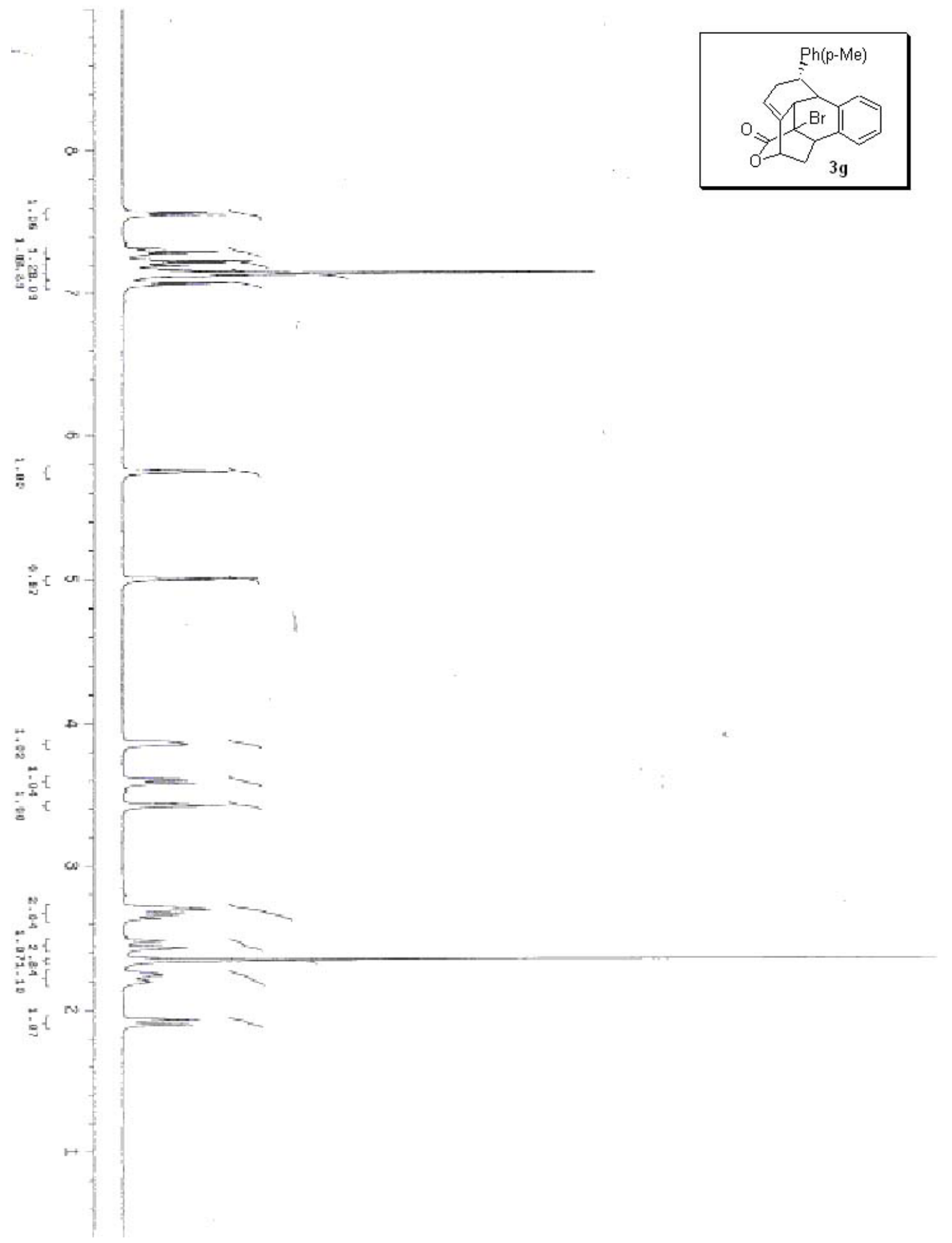




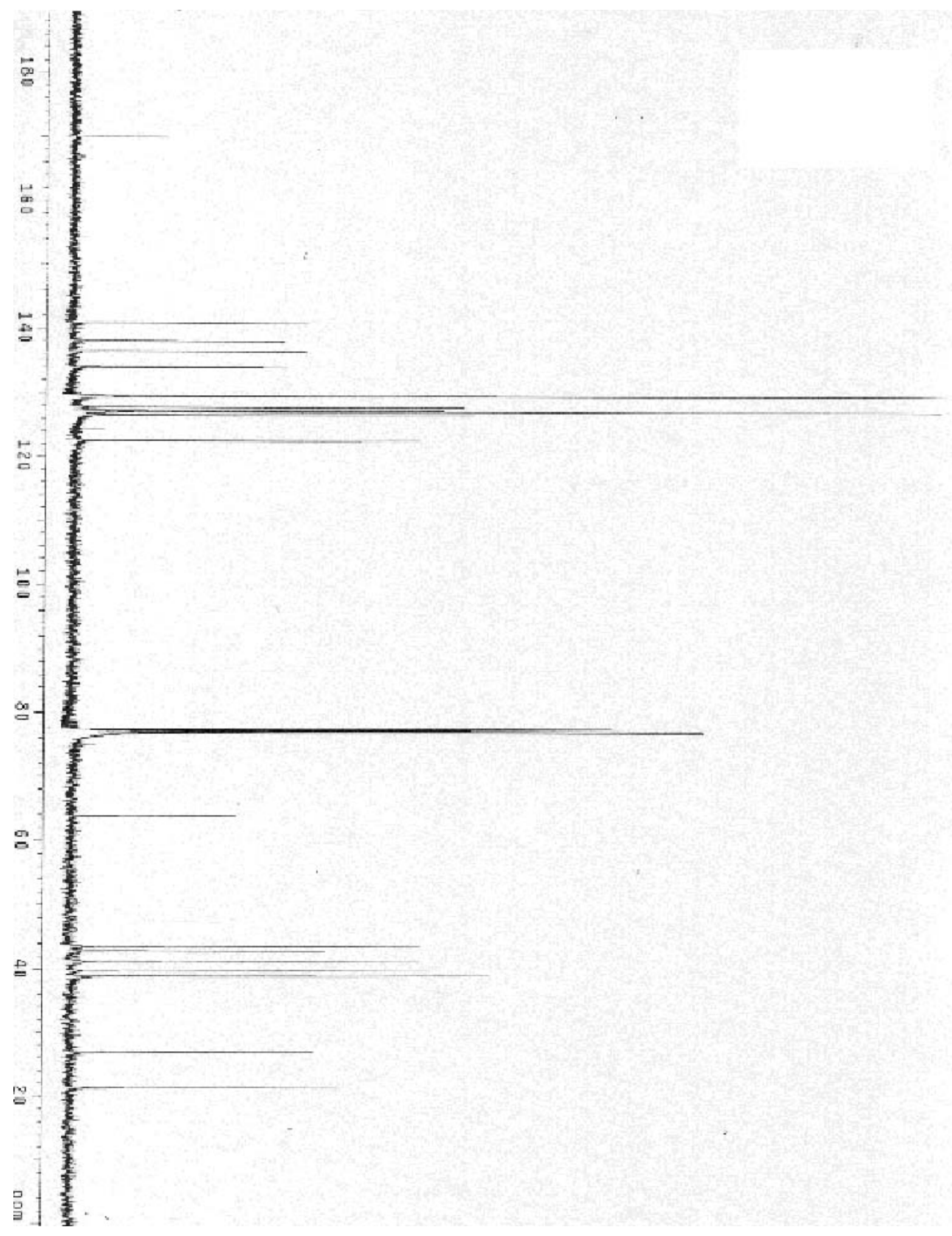




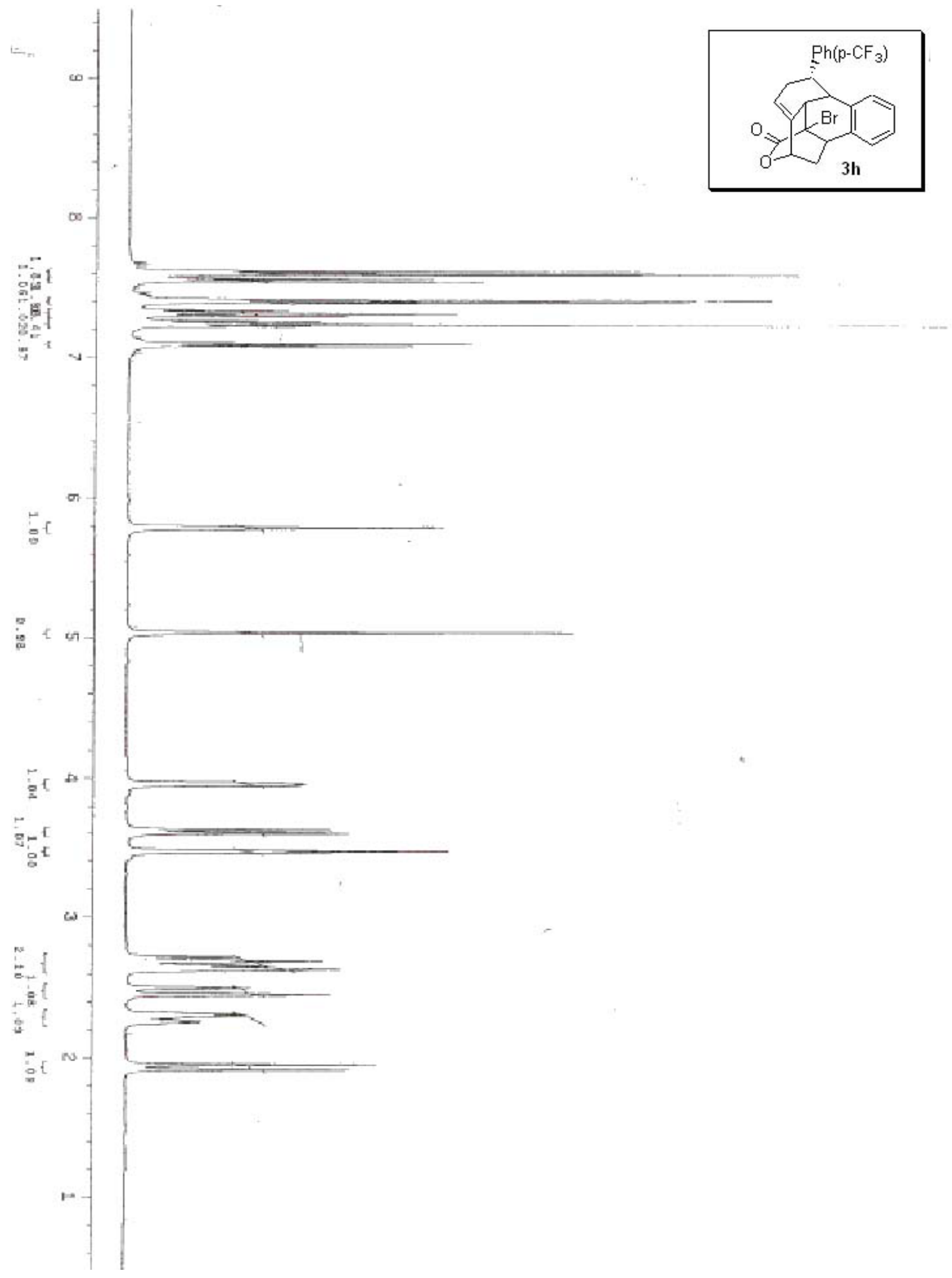




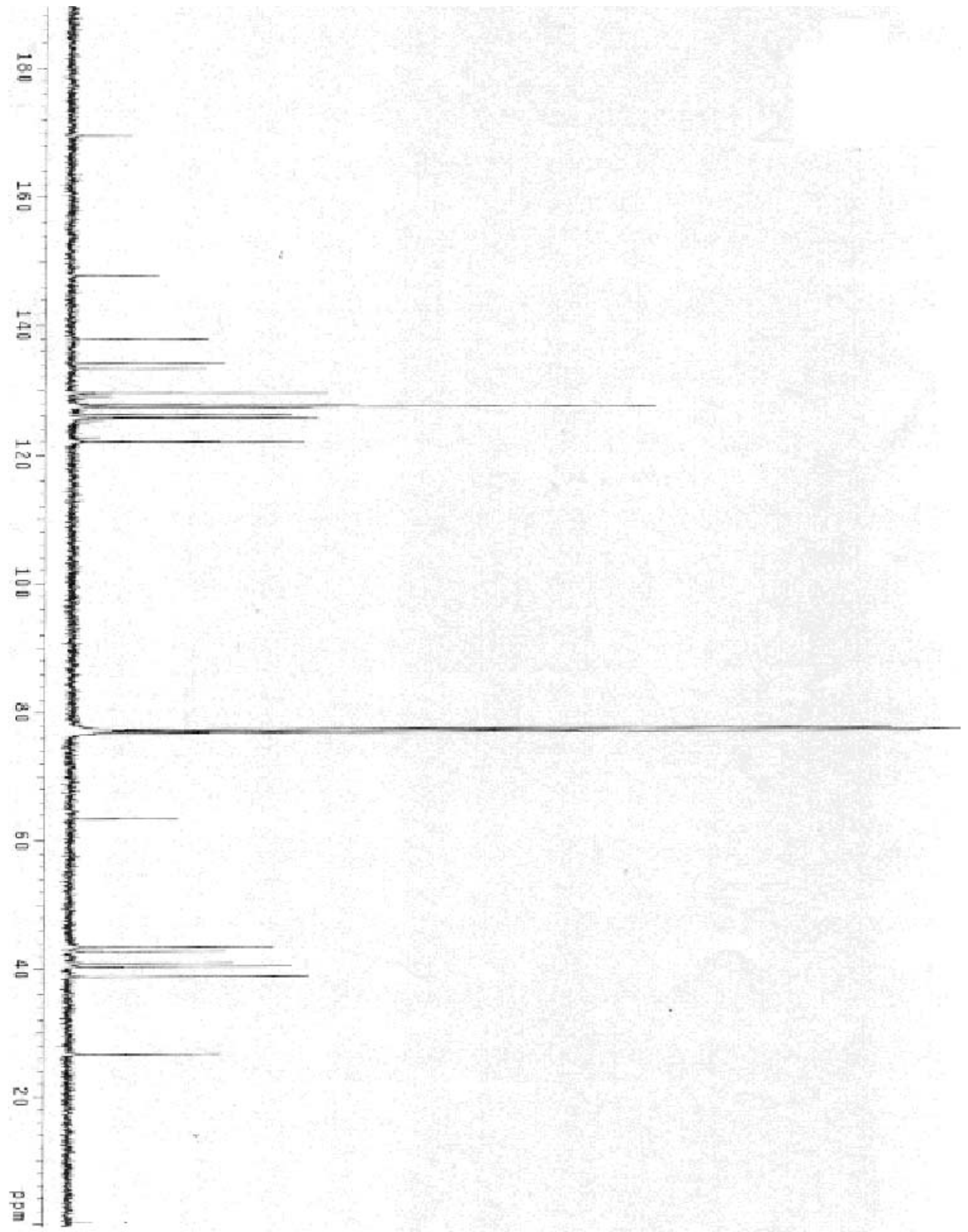




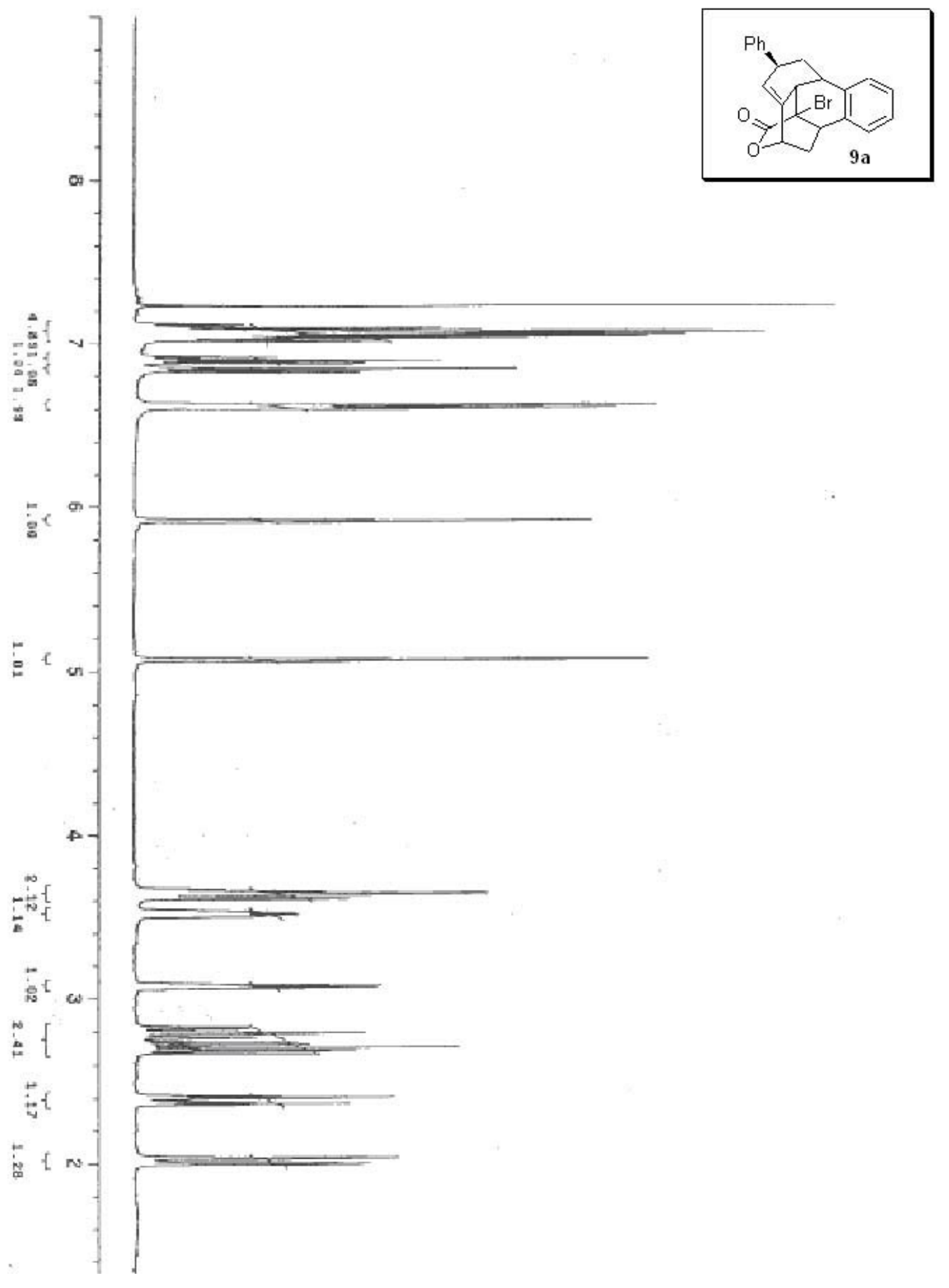




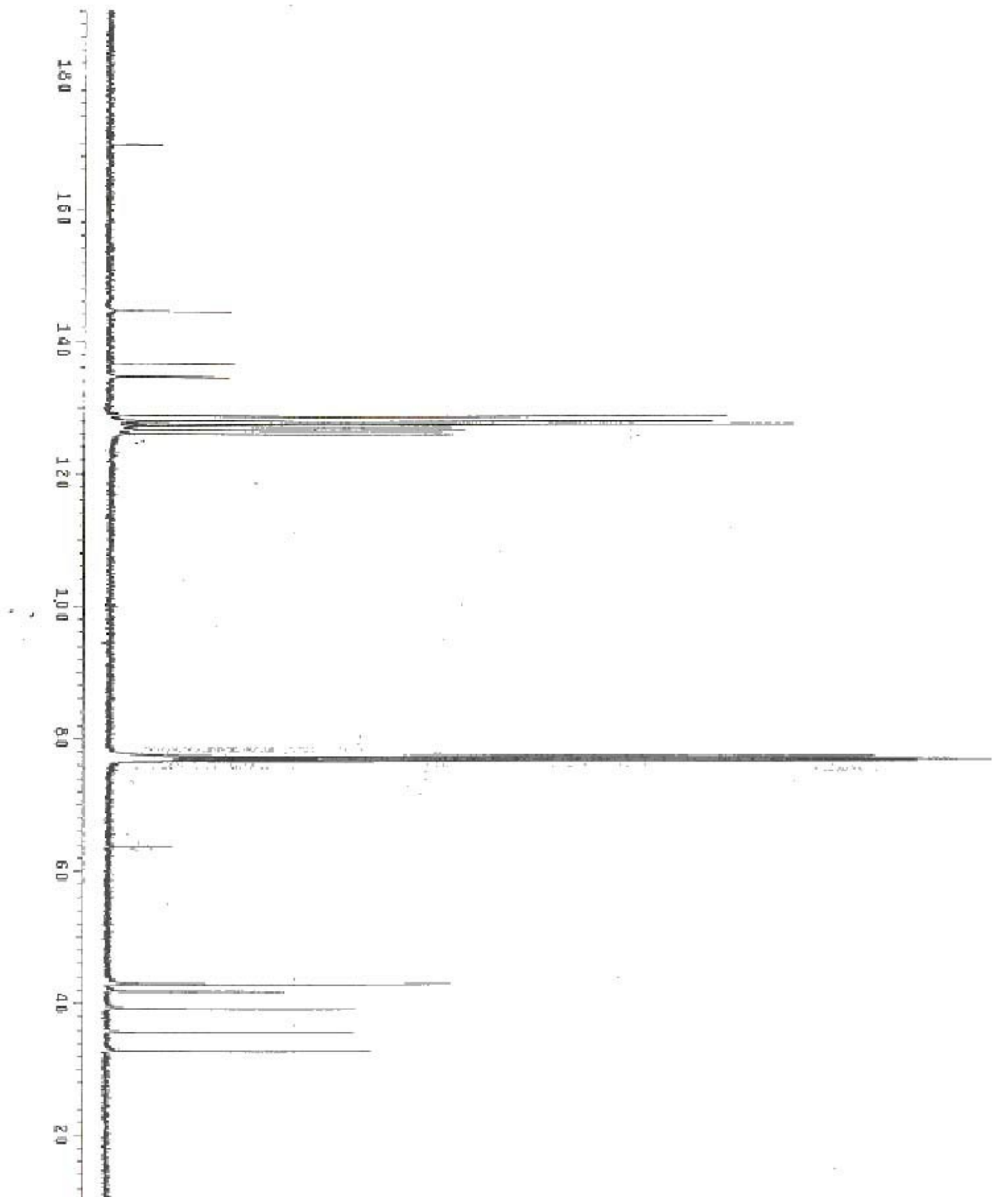




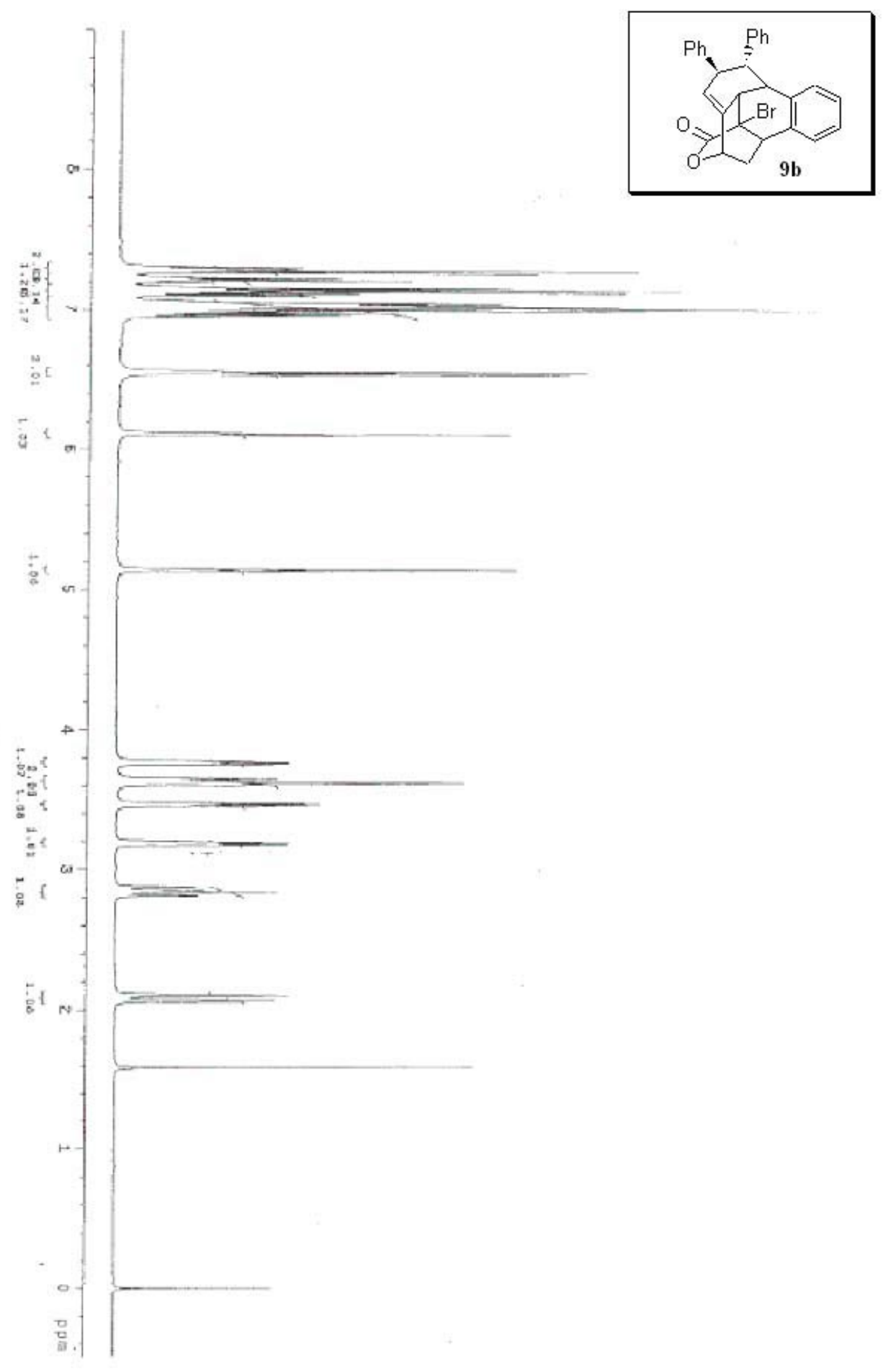




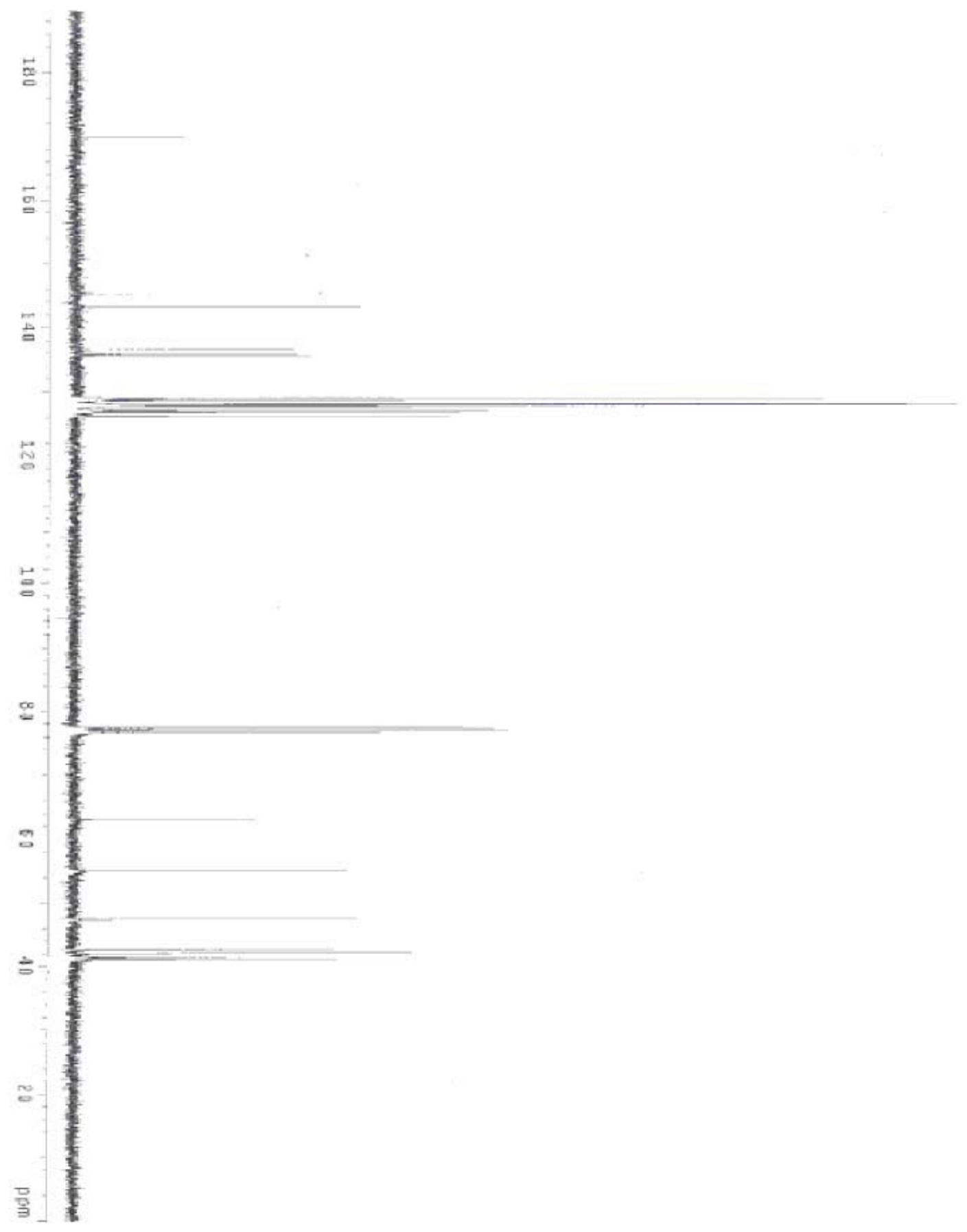




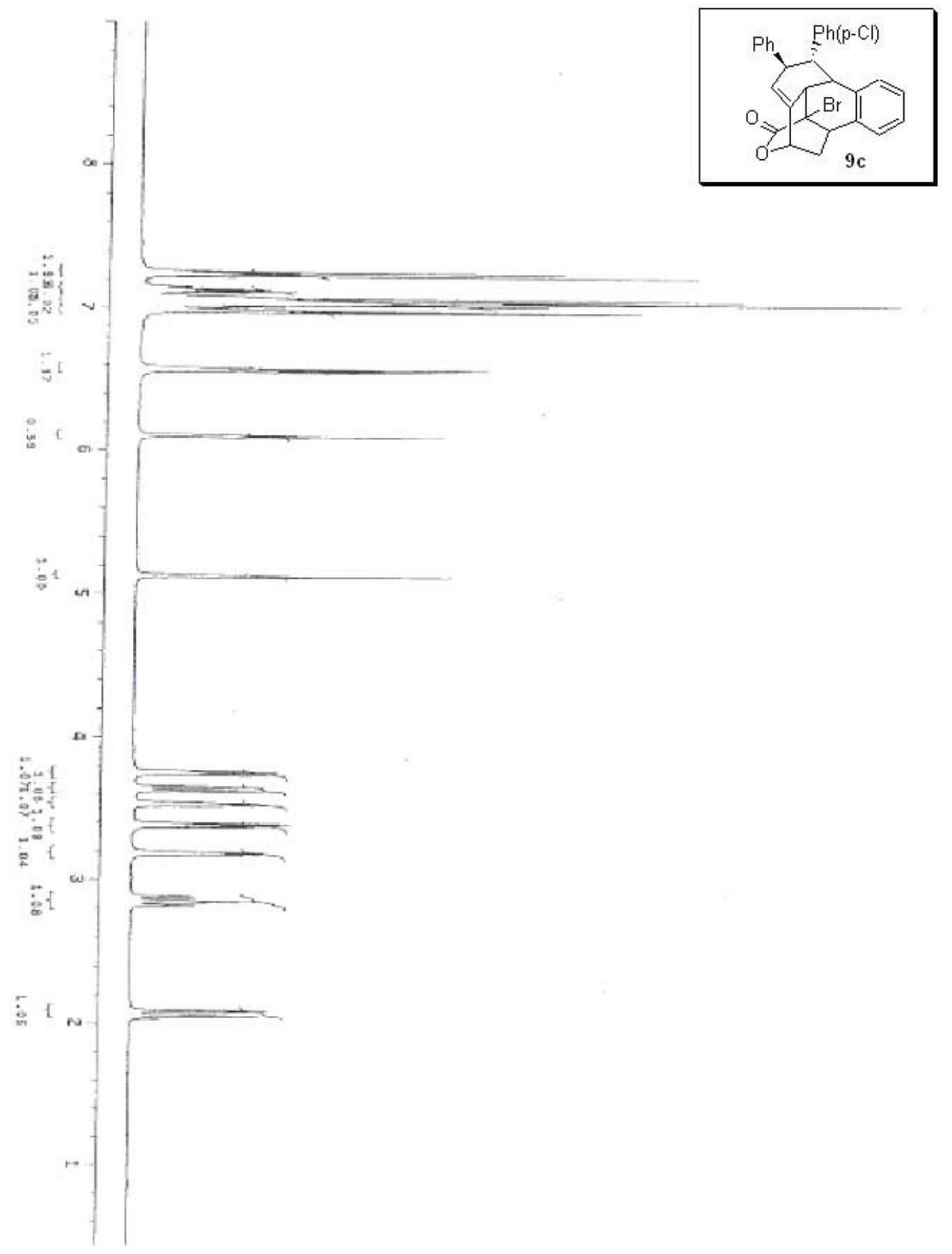




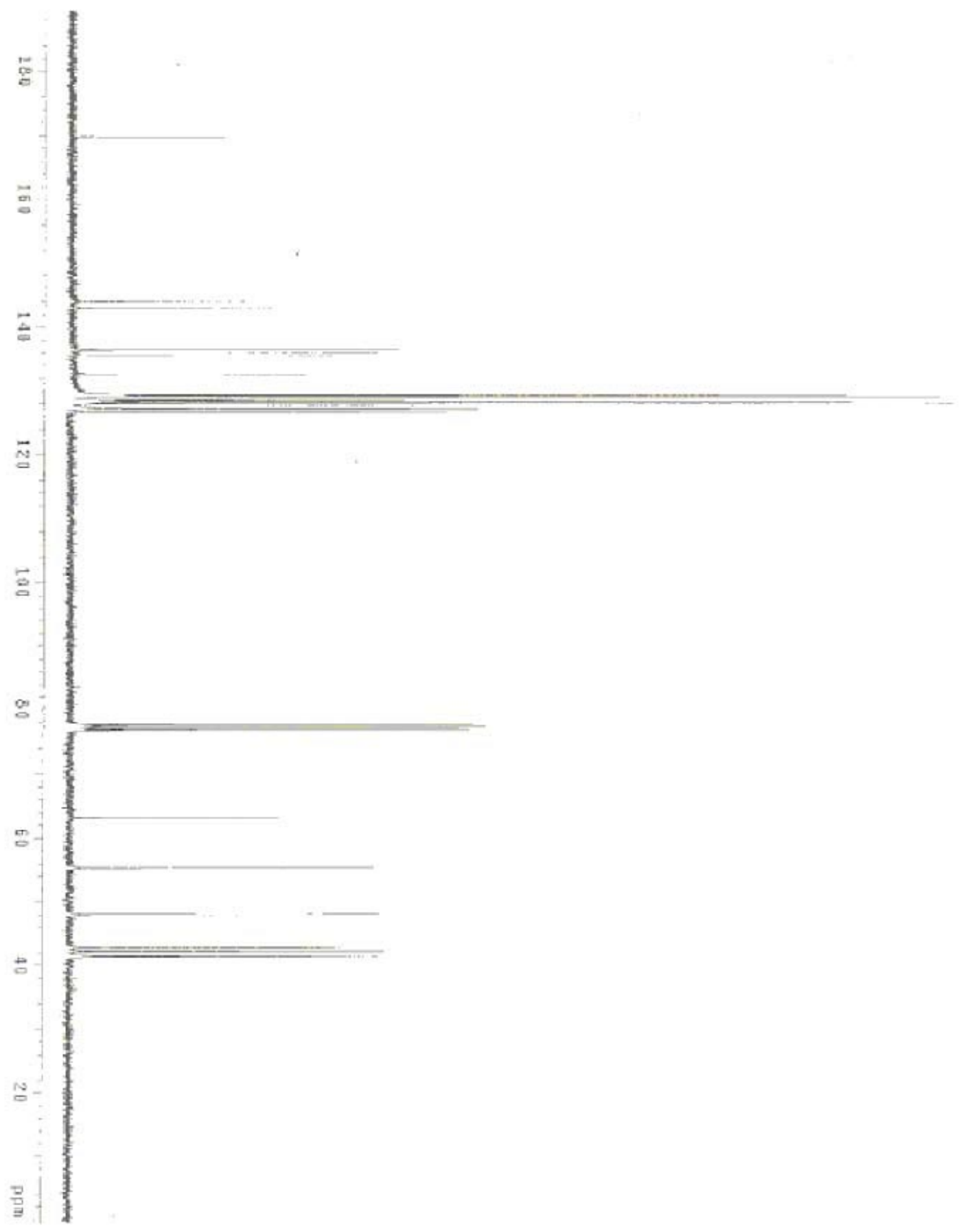

$\mathrm{S} 20$ 


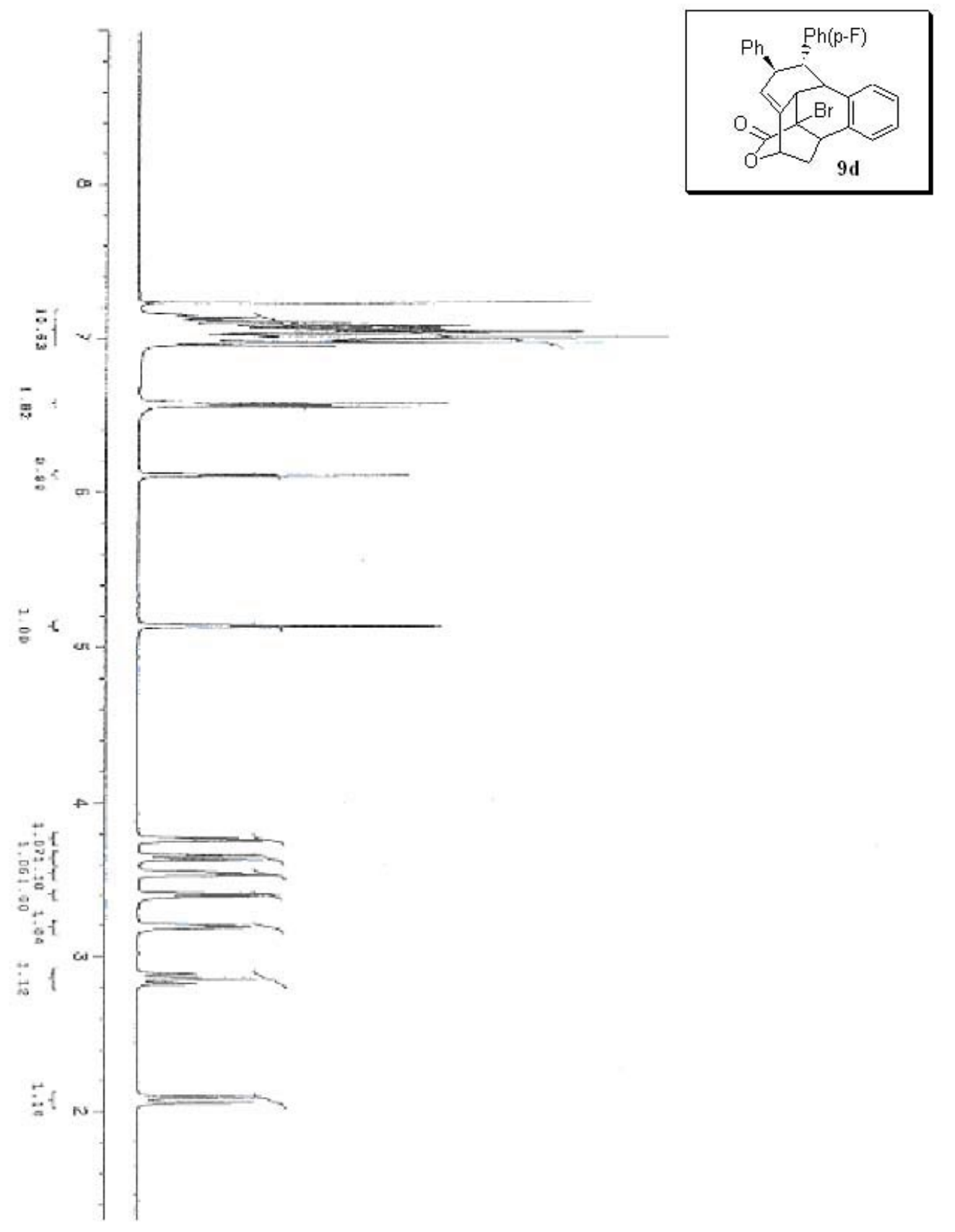




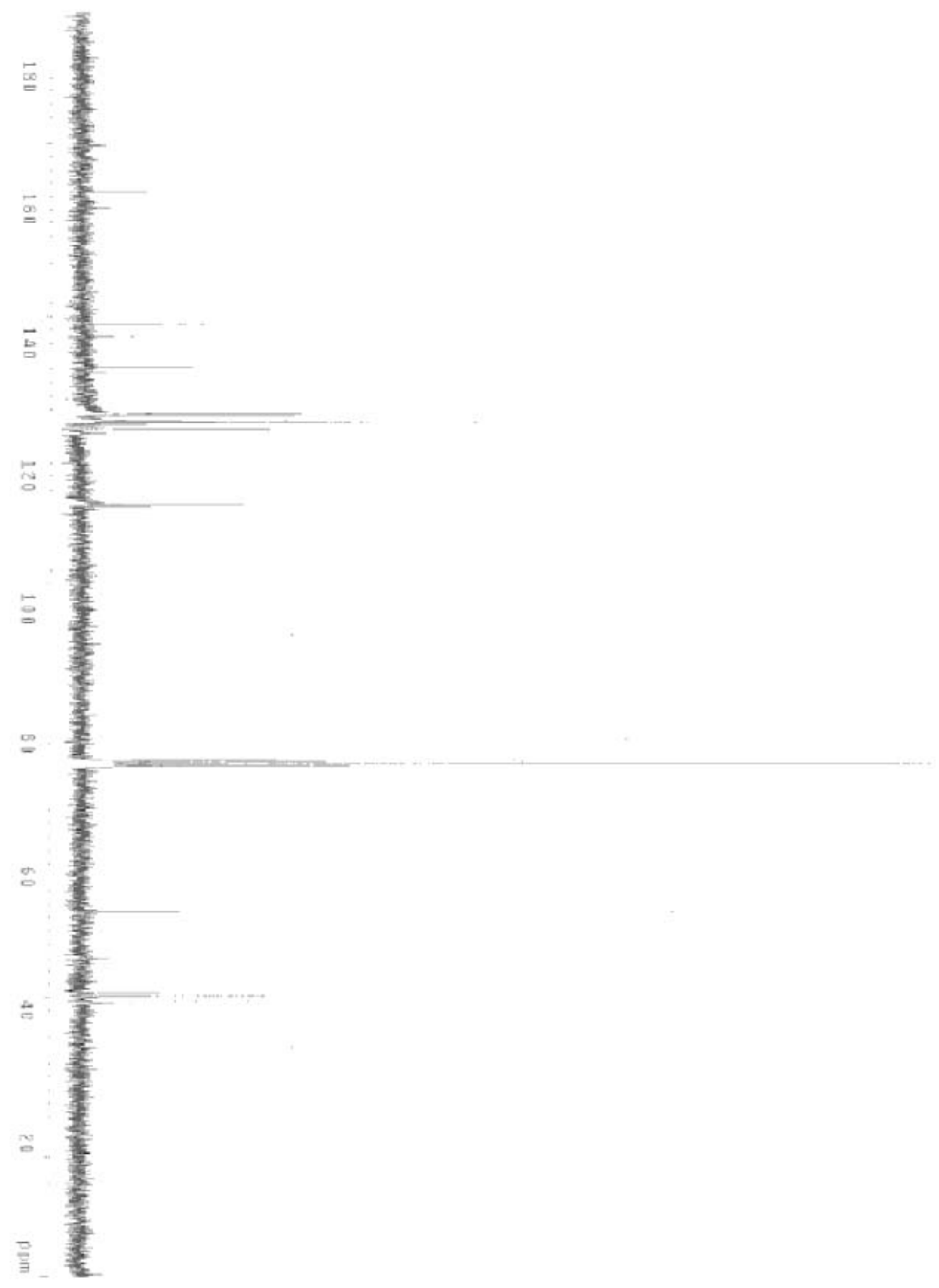




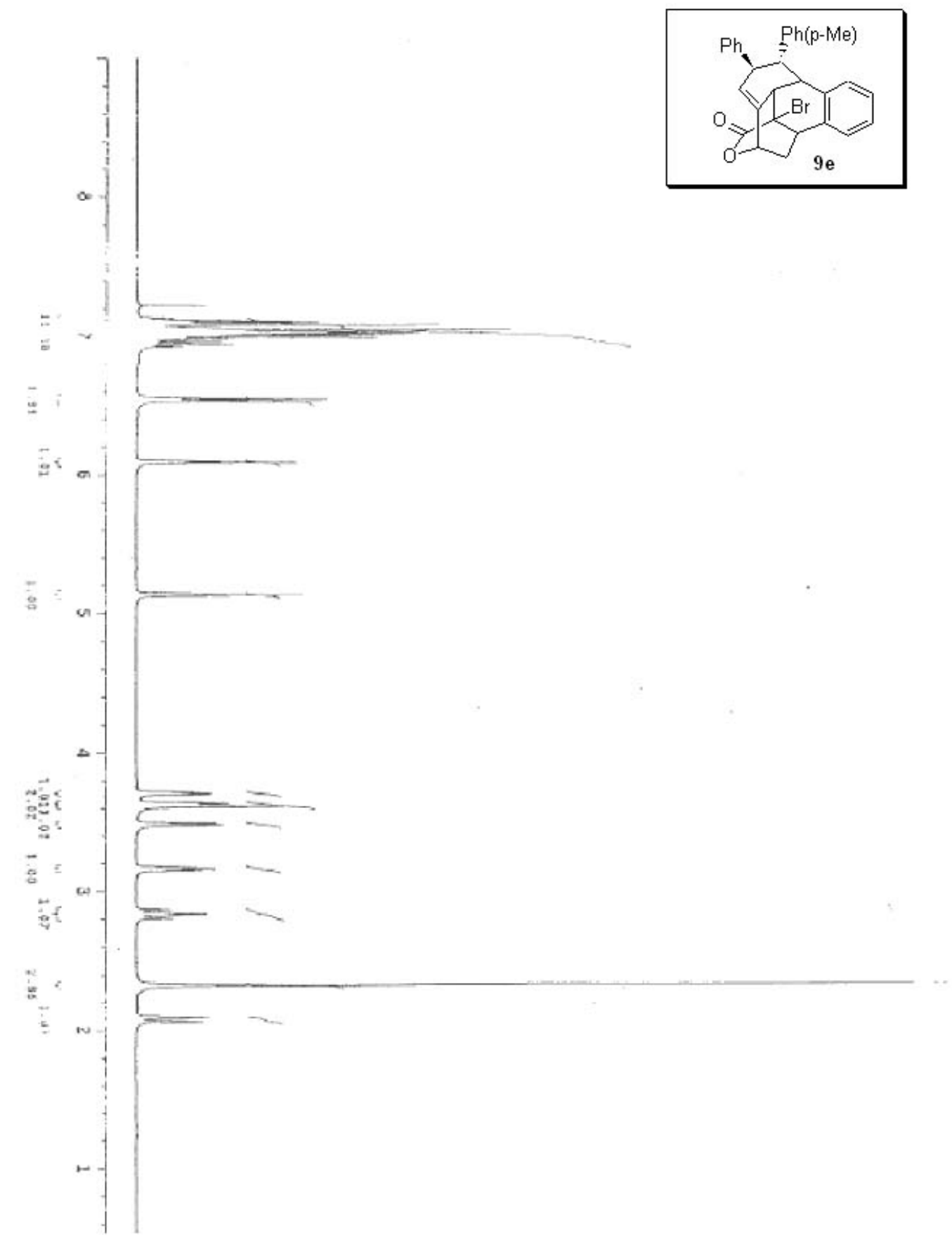




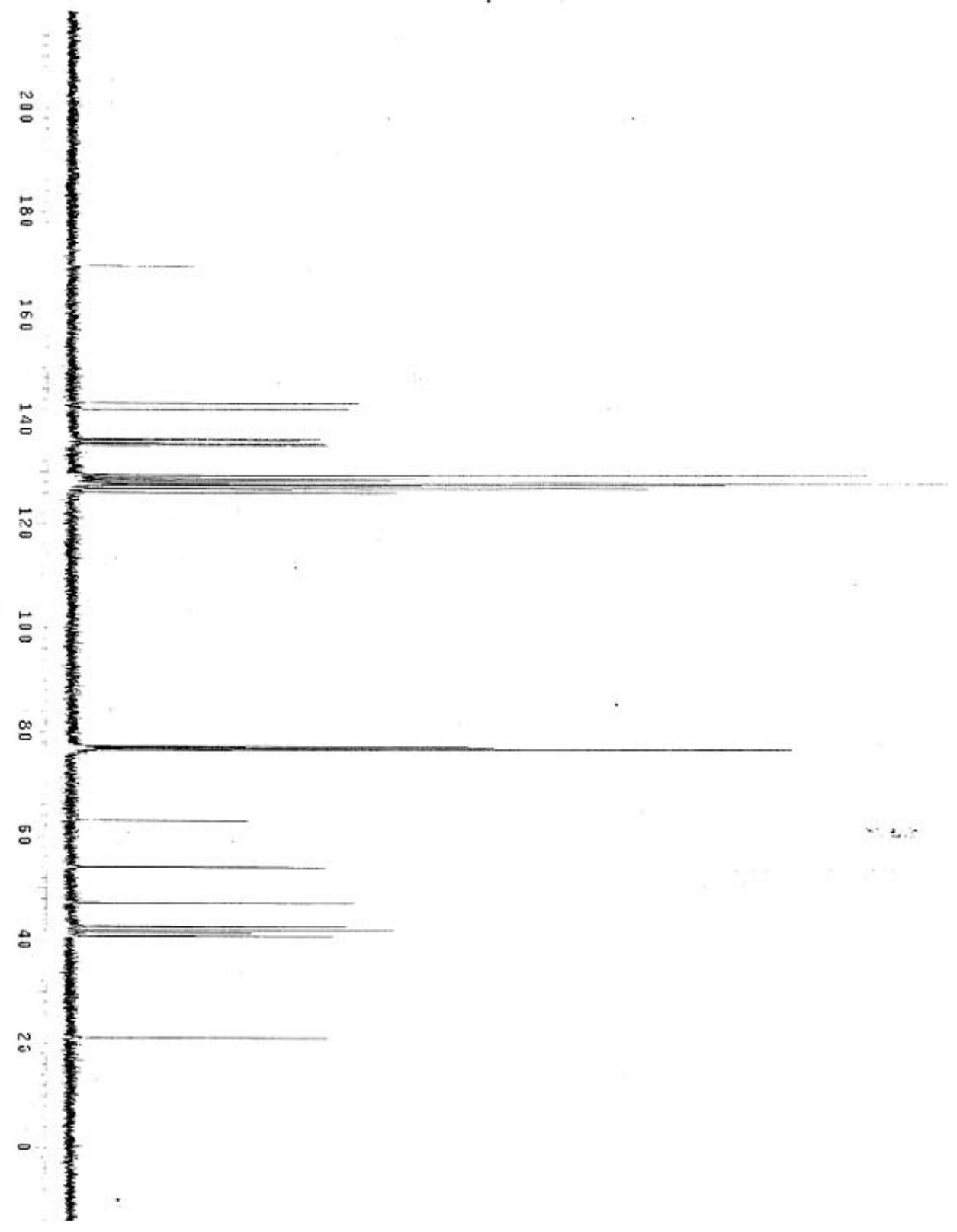




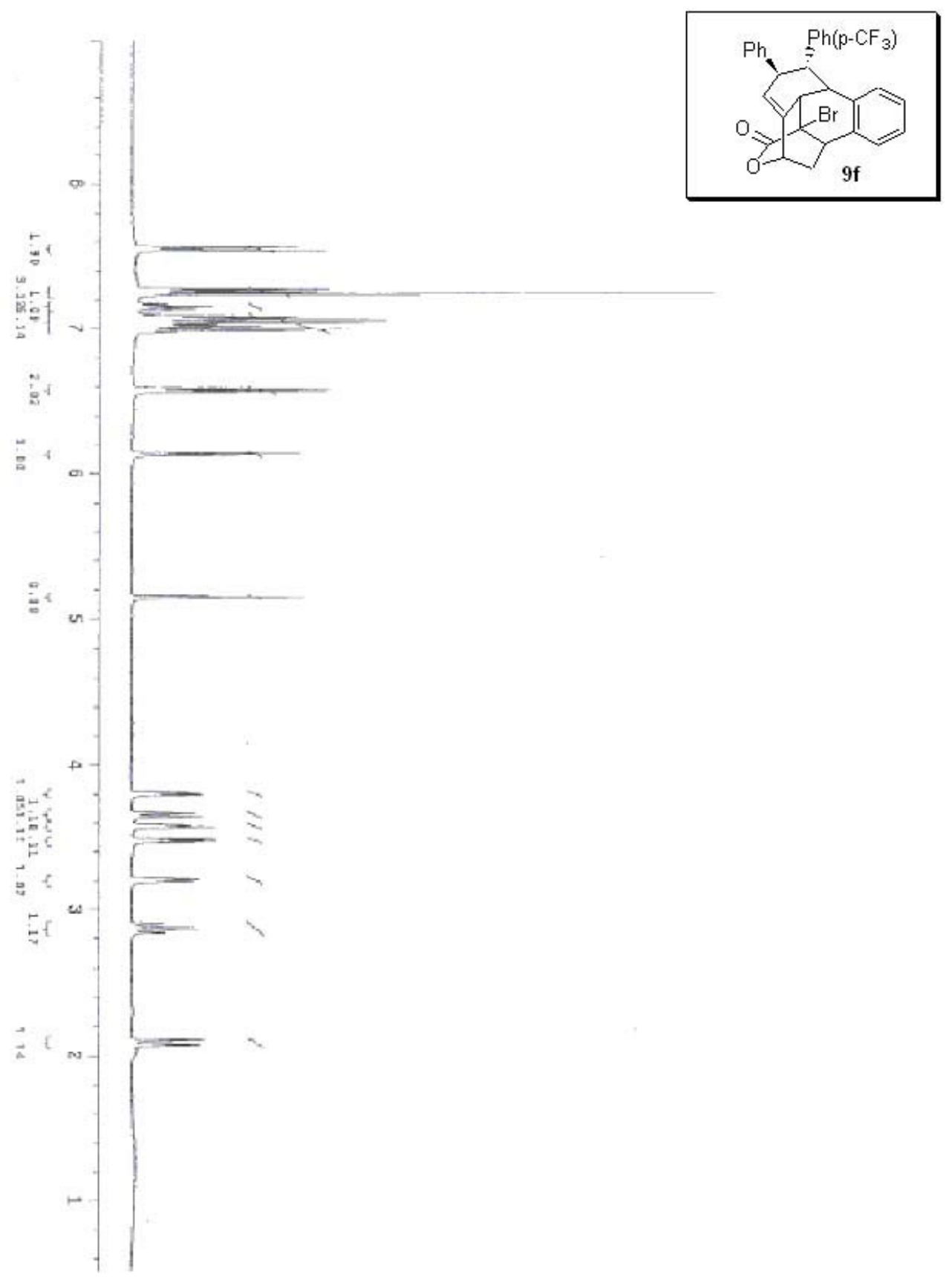




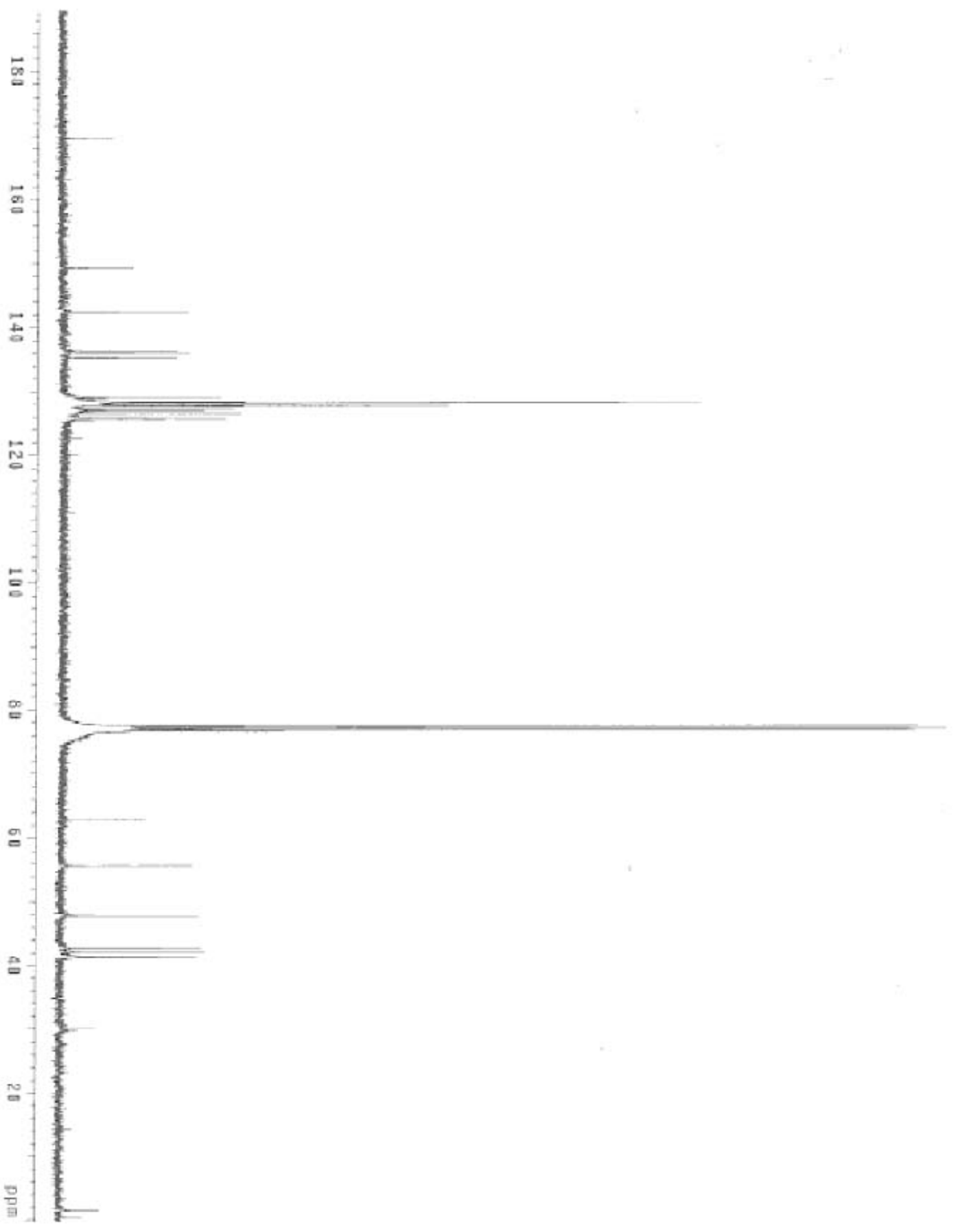




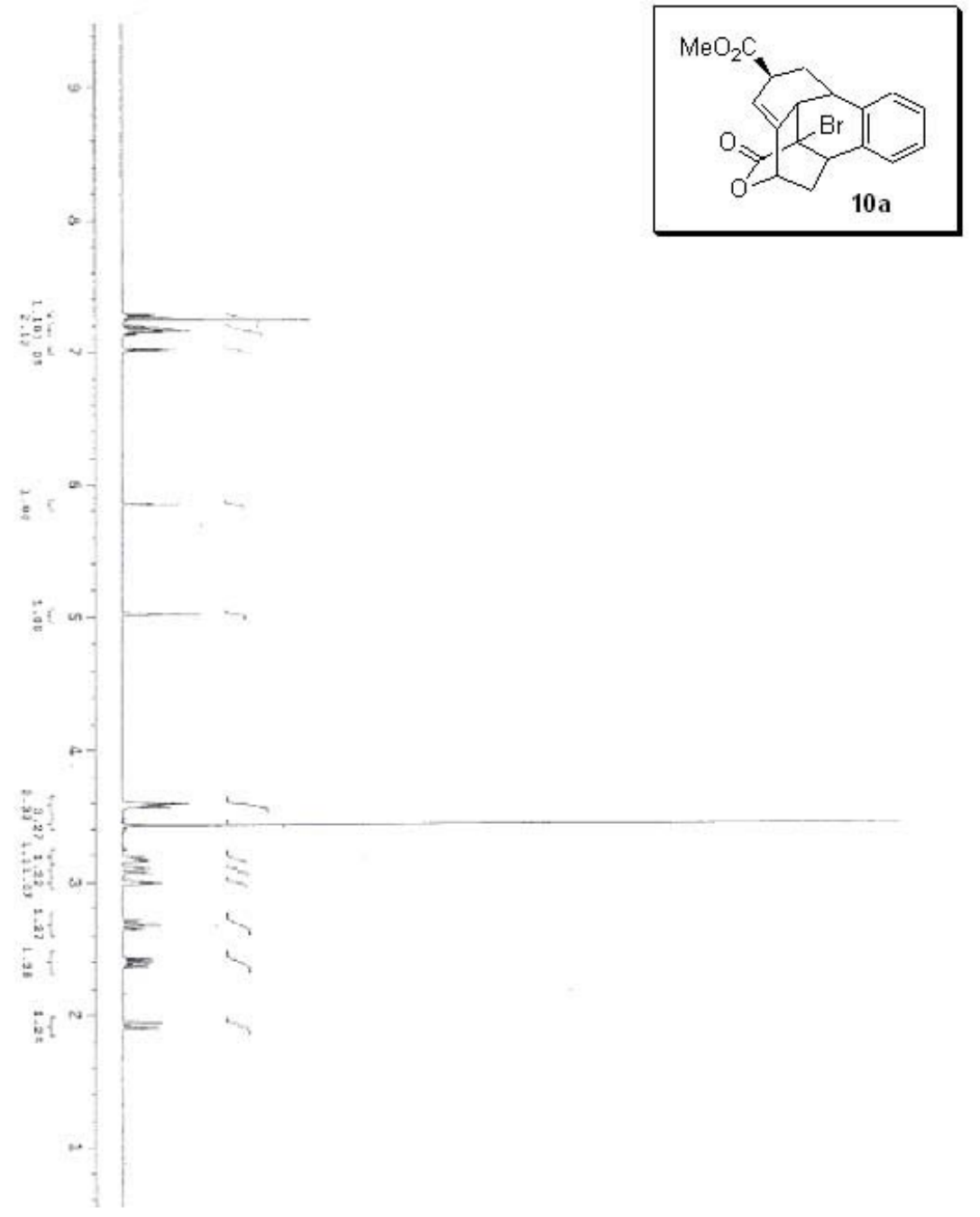




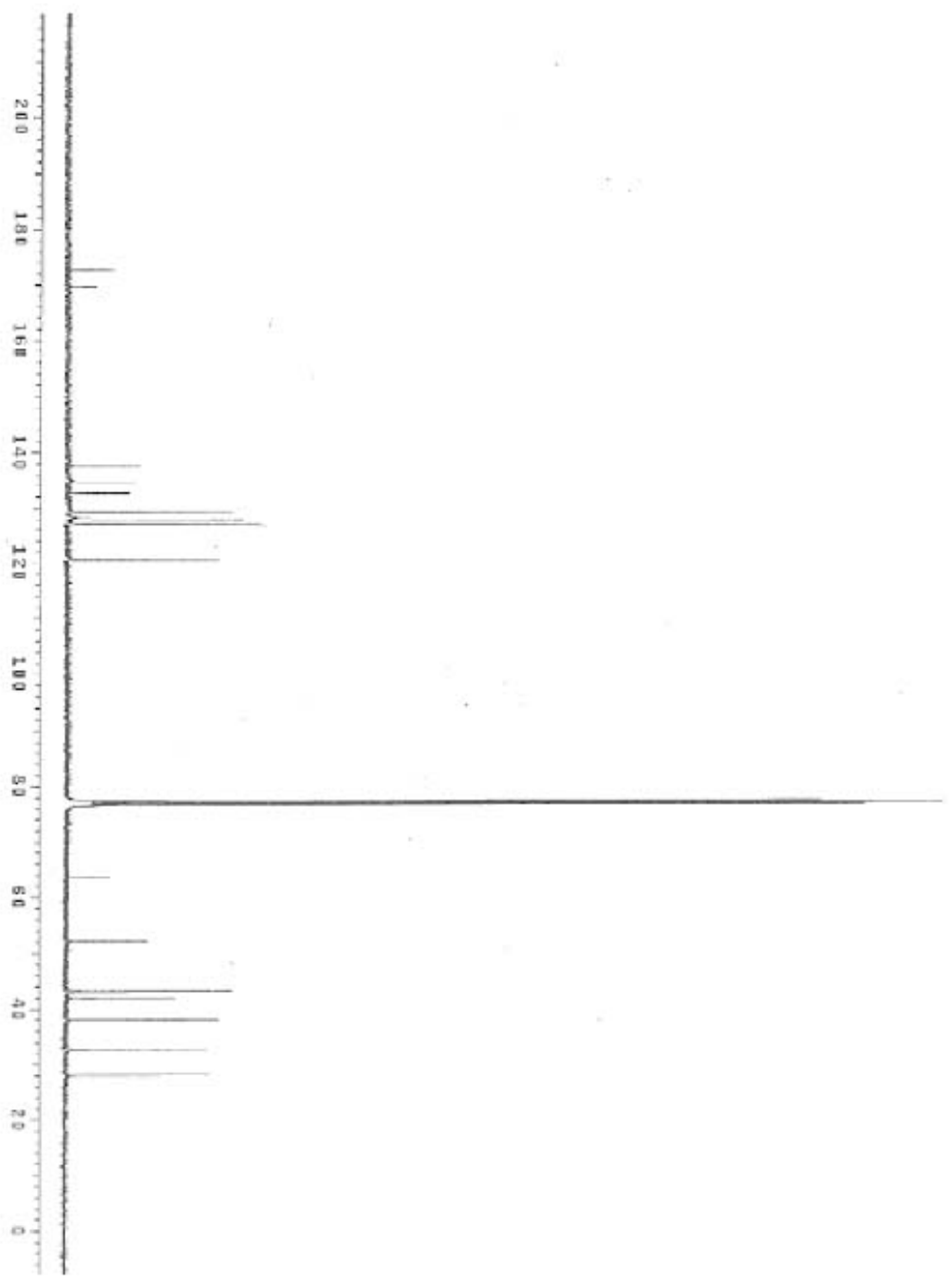




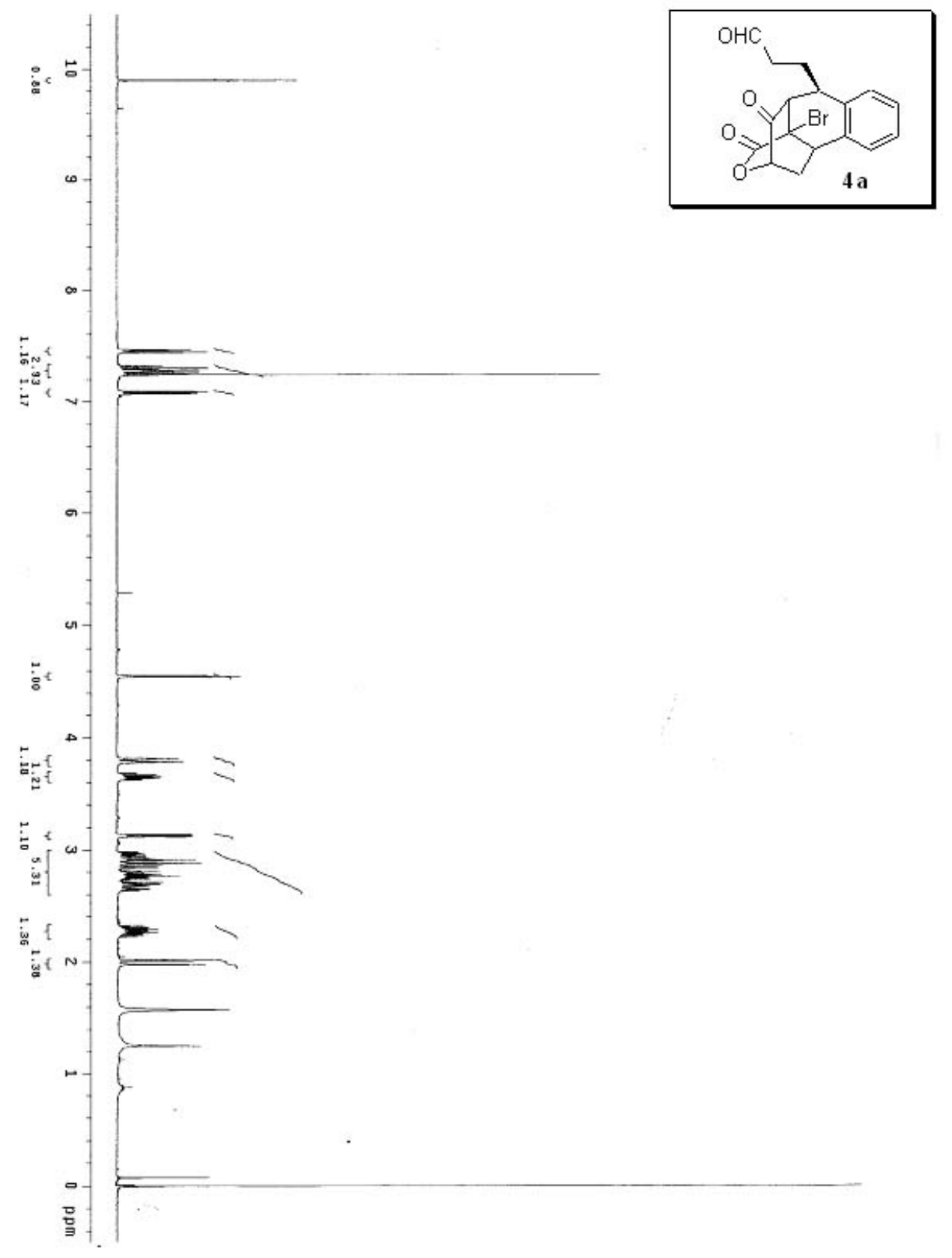




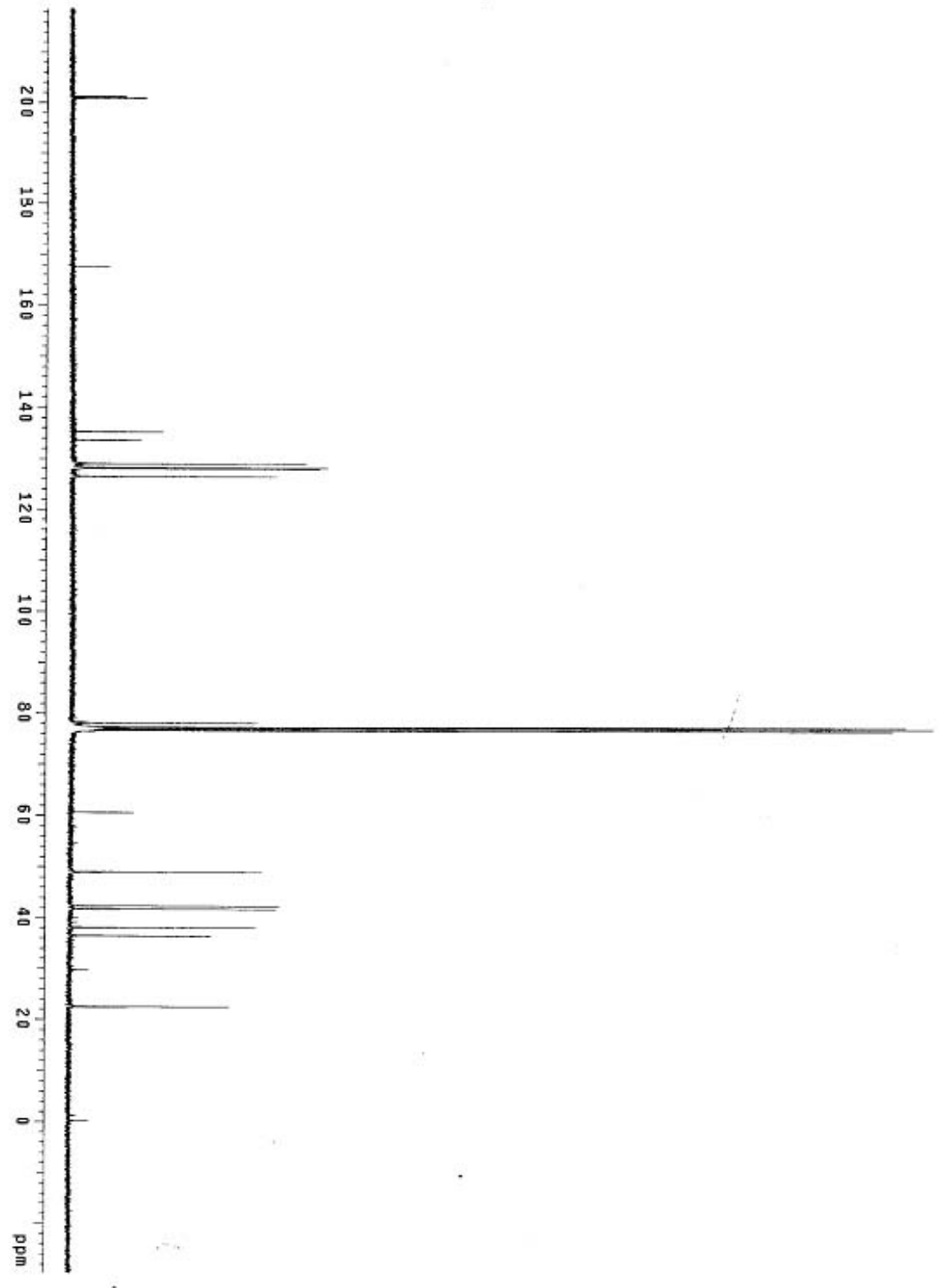

